\title{
Elaboration of a Cartographic Model of Zones Favorable to the Implantation of Water Points: Case of the Watershed of Ehania, South-East of Côte D'Ivoire
}

\author{
Dibi Brou1, Konan-Waidhet Arthur Brice1, Kouadio Boyossro Hélène², Savané Issiaka ${ }^{3}$, \\ Jean Biemi ${ }^{2}$ \\ ${ }^{1}$ Department of Environment, University of Jean Lorougnon Guedé, Daloa, Côte D’Ivoire \\ ${ }^{2}$ Department of Earth Sciences and Mining, University of Felix Houphouet Boigny, Abidjan, Côte D’Ivoire \\ ${ }^{3}$ Department of Environment Management, University of Nangui Abrogoua, Abidjan, Côte D’Ivoire \\ Email: dibrou2003@yahoo.fr
}

How to cite this paper: Brou, D., Brice, K.-W.A., Hélène, K.B., Issiaka, S. and Biemi, J. (2019) Elaboration of a Cartographic Model of Zones Favorable to the Implantation of Water Points: Case of the Watershed of Ehania, South-East of Côte D'Ivoire. Journal of Water Resource and Protection, 11, 1503-1514.

https://doi.org/10.4236/jwarp.2019.1112088

Received: October 22, 2019

Accepted: December 21, 2019

Published: December 24, 2019

Copyright $\odot 2019$ by author(s) and Scientific Research Publishing Inc. This work is licensed under the Creative Commons Attribution International License (CC BY 4.0).

http://creativecommons.org/licenses/by/4.0/

\begin{abstract}
The supply of drinking water from aquifers of base remains problematic because of his complexity. The combination of several methods is more adapted for the mapping of water establishment favorable areas. This study is focused on water points establishment favorable areas mapping. The methods used are remote sensing, pump tests sheets for determining aquifers and saprolites thickness. To determine the recharge, GR2M Method and drainage density has been used. The digital elevation model (DEM) has been used to generate slopes and drainage density maps. The thematic maps obtained combined under GIS to produce water potentiality map. The results obtained have been with exploitation rates. Three classes of potentialities have been identified. These are classes of high potentialities in groundwater which cover approximately $20 \%$ of the study area. It occurs mainly in central areas where there are sedimentary formations usually captured by the drilling. These areas are generally located in the central part, mainly in areas where there is low slope, important with a thick layer of saprolites.
\end{abstract}

\section{Keywords}

Drinking Water, Bases Aquifers, GIS, Multicriteria Analysis (MCA), Water Points Establishment

\section{Introduction}

Groundwater is the most important source of fresh water in the world and pro- 
vides a lower risk to support the requests of critical water during dry periods cyclical and prolonged [1]. They play an important role in the satisfaction of requirements in water supply despite the flow rates relatively low as indicated in some work [2]. If in the continuous aquifers the accessibility of these resources is easy, it is not the case of the discontinuous aquifers (usually bilayer) of crystal formations and crystallophyllian. The exploitation of these aquifers is very difficult because of underground hydrogeological transfer complexity which depends in particular on the nature of the rocks, geological structure, the rainfall, the connectivity between the flaws [3]. In these areas, storage and recharge conditions are poorly assured because of this complexity. Its exploration and exploitation requires the use of several methods including Proton Magnetic Resonance (RMP) that is a geophysical method [4]. This method allowed to determine the thicknesses. Other isolated methods have also shown their importance for the assessment of groundwater potential. Some methods are the charging, the water level in the aquifer [5], and the fracturing [6]. As well, the potential for groundwater remains controlled by several parameters. However, the complexity of the Environment doubled the variability of these parameters involves taking into account each parameter whose importance varies with the area. These last years, the study of the cracked environment has very often been associated with the remote sensing which allowed identifying the bone fractures prior to confirm their real existence by Geophysic method. The shortcomings of these methods could explain the rate of failure that still remains high, often reaching 40\% [7] in Benin. These methods although effective, may not provide important results if they are taken individually, especially in area of stand; this is the case of the Ehania catchment. All these méthods should then be to integrate in a cartographic model such as GIS and the Multicriteria Analysis (MCA). The water potential area modeling of potential in water has already been the subject of several studies from around the world [8] [9] [10]. However, these studies remain limited in not only the choice of parameters but also the importance of these parameters. The objective of this study is a set up cartographic model to delineate zones favorable to water point implantation.

However, the Ehania watershed, site of this study, is located in the base which covers about $97.5 \%$ of the Ivorian territory. In this area, the flow rates of the drilling obtained remain relatively low despite that the area is relatively well watered by of our many courses of water with a rainfall relatively abundant (2000 $\mathrm{mm} /$ year) [11].

\section{Material and Methods}

\subsection{Presentation of the Study Area}

The watershed of Ehania (Figure 1) site of this study is located in the extreme south-east of Côte D'Ivoire between $2^{\circ} 45^{\prime} \mathrm{W}$ and $3^{\circ} 105^{\prime} \mathrm{W}$ longitudes as well as the latitudes $5^{\circ} 10^{\prime} \mathrm{N}$ and $5^{\circ} 45^{\prime} \mathrm{N}$ latitudes. It covers approximately $342 \mathrm{~km}^{2}$.

The geological formations are dominated by schists toward the North with the 


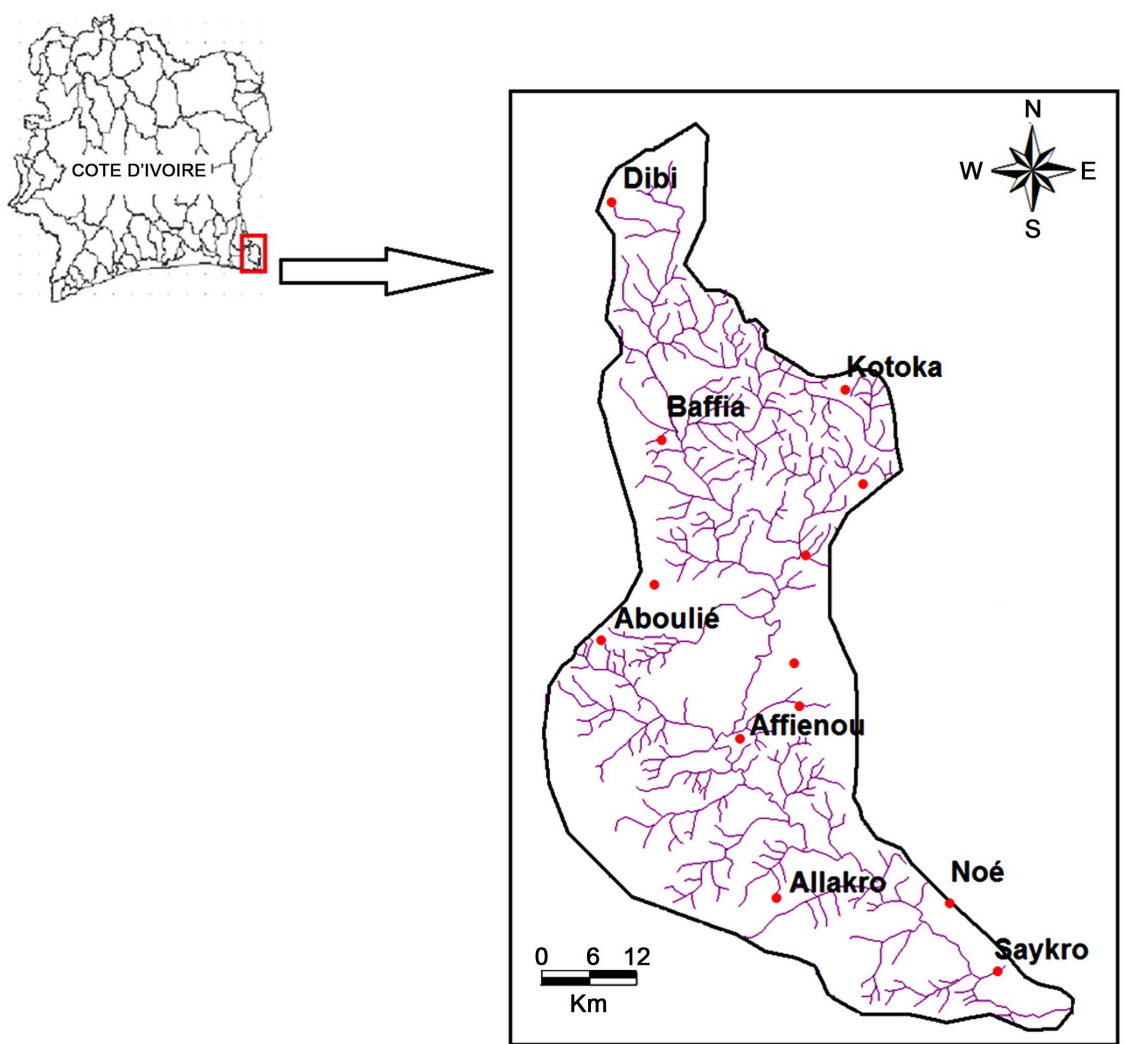

Figure 1. Study area.

appearance of a thin layer of sediment in the South through a few shreds of granites. Concerning the topography, the site is composed of high plateaus with altitudes ranging generally 100 to $400 \mathrm{~m}$. The hydrographic network which is considered as an indicator of aquifers recharge is denser in the North than in the South.

\subsection{Materials}

The material used in this study is composed of:

- The field data collect with potentiometric probe and GPS;

- Cartographic and alphanumeric data, software and borehole data (static level, thickness of alteration, and flows of operation);

- Cartographic data and images that are represented respectively by the topographic and geologic maps of leaves of Grand-Bassam on the one hand and other parts by the satellite images of Landsat 7 (196-55 scene acquired in February 2000) and the images of the SRTM (Shuttle Radar Topography Mission) of the year 2000. Two software maps have been used (MapInfo and ArcGIS) as well as image processing software (Envi 4.1).

\subsection{Methods}

\subsubsection{Intrinsic Characteristics of the Aquifer}

Slope: It represents one of the factors which control the infiltration. It is a 
critical parameter that controls directly the runoff and therefore the infiltration [12]. In effect, with a low slope, runoff is slow and allows rainwater to seep into the sub-soil, while the areas heavily tilted facilitate the runoff [13]. The STRM images have been merged and have helped to define the boundaries of the study area which is the Ehania watershed. A watershed limit mask was superimposed on the SRTM images and the study area has been extracted. The treatment of the image thus extracted has helped to generate the Map of slopes from the software ArcGIS. It varies from 0 to the border of the lagoons to $30 \%$ in the east of the study area.

Thickness of the saprolite is regarded as the less important parameter in the mapping of areas favorable to groundwater availability [9]. However, some recent works have shown the importance of alterite thicknesses, especially at the level of crystalline rocks, which could constitute a aquifer level very interesting for drinking water supply [14]. According to [13], the availability of the groundwater is classified as low to moderate in the areas with a thin layer and is evolving in moderate to good in the areas with an altered layer thick. In the case of this study, the altered layer has been obtained from the data sheets of drilling and ranged from 2.25 to $68 \mathrm{~m}$. A roof model of the base has been achieved. This model coupled with the thicknesses map has helped to produce the layer of saprolites.

Density of fracturing (DF) has been developed from the map of fracturing obtained from ETM+ satellite images of Landsat 7 with the scene 196-55 of February 2000 which have undergone a spatial filtering. The fracturing map makes account of the permeability of the medium in area of cradle especially when these fractures communicate, as it is the case of our study area, making this environment equivalent continuous one.

\subsubsection{Characteristics Related to the Presence of Water}

Recharge: It has been calculated from the combination of infiltration determined from the model of Rural Engineering 2 Monthly time steps (GR2M) and drainage density. The charging importance of groundwater availability has already been shown through several studies ([8] [15]). The drainage density represents the precipitation amount which could seep into the basement. Therefore, the higher the drainage density is, the higher the recharging probability is [13]. The drainage density map has allowed producing 5 classes of $25 \mathrm{~km}^{2}$ ranging from low to high. The coefficients range from 1/5 (lowest drainage density) to 5/5 (highest density) [9]). Affecting these coefficients to the infiltration which remained a single value of $397 \mathrm{~mm}$, the recharge values would, therefore, advance from 77 to $397 \mathrm{~mm}$.

Depth of the water represents the static levels and indicates the level of water in aquifers. They play an important role in the groundwater potential areas mapping [16]. This importance has yet been shown through the work of [17] which addressed the close link between the recharge and water levels in the aquifer. Indeed, the greater the charge is, the higher the water level increases. But this increase could either be delayed or directly, depends on the nature of alte- 
rites. In the study area, the map of the static level was developed from data from the observed piezometric on the ground. This static level varies from 1.96 to 63.8 $\mathrm{m}$.

\subsubsection{Calculation of Weighting Coefficients}

The weighting factor calculation is done from the method of [18] based on the comparison in pairs developed by El Morjani (2003) and adapted by [19] (Table 1).

The values from this comparison have subsequently been integrated as follows [9].

$$
V_{p_{i}}=\sqrt[n]{\prod_{i=1}^{n} N_{i}} \text { and } W_{i}=\frac{V_{p_{i}}}{\sum_{i=1}^{n} V_{P_{i}}}
$$

With $V_{P_{i}}=$ eigen vector of each factor; $N_{i}=$ value of each factor or criterion and (WI) the weighting coefficient (WI) of each factor.

On this basis, correlation matrices have been developed for each criterion to determine the level of each cell the value of the intrinsic characteristics of the factor criteria of the aquifer (Table 2) and those of the water resources factor (Table 3).

Table 1. Verbal and numerical expression of the relative importance of a factors pair as amended by Dibi et al. (2015).

\begin{tabular}{cc}
\hline Verbal expression of the relative importance of a criterion relative to another & Ratings \\
\hline Less important & $1 / 3$ \\
Slightly less important & $1 / 2$ \\
Same importance & 1 \\
Slightly more important & 2 \\
Most important & 3
\end{tabular}

Table 2. Table of coefficients of weighting of the criteria of the factor intrinsic characteristics of the Aquifer.

\begin{tabular}{cccccc}
\hline & Slope & Saprolite & DF & Eigen vector & Coef \\
\hline Slope & 1 & 2 & 2 & 1.71 & 0.38 \\
Saprolite & $1 / 2$ & 1 & 2 & 1.52 & 0.34 \\
DF & $1 / 2$ & $1 / 2$ & 1 & 1.26 & 0.28 \\
\hline
\end{tabular}

Table 3. Table of weights to the criteria of the water resources factor in the aquifer.

\begin{tabular}{ccccc}
\hline & Recharge & Depth. & Eigen vector & Coef. \\
\hline Recharging & 1 & 3 & 2 & 0.60 \\
Depth & $1 / 3$ & 1 & 1.15 & 0.40 \\
\hline
\end{tabular}




\subsubsection{Potential Areas Mapping Elaboration}

The development of the potential area maps has been done from the GIS and the Multicriteria analysis (MCA) by the combination of the different factors that are the intrinsic characteristics (Ci) of the aquifer and water resources (Re) (Table 4). These factors will also be the subject of a weighting taking account of their contribution in water availability.

Table 4. Table of weighting coefficients of the potentialities of water resources.

\begin{tabular}{ccccc}
\hline & Intrinsic characteristics & Depth. & Eigen vector & Coef. \\
\hline Intrinsic characteristics & 1 & 3 & 2 & 0.60 \\
Water resources & $1 / 3$ & 1 & 1.15 & 0.40 \\
\hline
\end{tabular}

From coefficients of weights, we determine the indices (Ip) that will allow to develop the different maps from the following equation:

$$
\mathrm{Ip}=\mathrm{WcCi}+\mathrm{WrRe}
$$

$\mathrm{Wc}$ and $\mathrm{Wr}$ are respectively weighting coefficient of intrinsic factors characteristics and water resources.

From the values of these coefficients, the Equation (2) becomes:

$$
\mathrm{Ip}=0.6 \mathrm{Ci}+0.4 \mathrm{Re}
$$

The results obtained have been validated by yield of borehole superior than 5 $\mathrm{m}^{3} / \mathrm{h}$ which indicates the presence of fracture.

\section{Results and Discussion}

\subsection{Results}

The use of the methods of GIS and MCA has helped to develop a set of layers which were regarded as criteria. Thus, the factor intrinsic characteristics of the aquifer (slope criteria, thickness of alterites, fracture density) and the Water Resource Factor (Charging criteria and depth of the aquifer) were produced; the combination has resulted in the water potential map.

\subsection{Aquifers Intrinsic Characteristics Factor}

The intrinsic characteristics make reference to the conditions of the existence or availability of water resources. The analysis of the results obtained by this criterion (Figure 2) highlights three classes ranging from classes of low to classes of high water availability. They cover respectively $10 \%, 60 \%$ and $30 \%$ of the study area. Among these classes, that terms of lives medium remain the class the most important and it is found on the whole extent of the study area. As regards the class of high availability which covers only $25 \%$ of this zone, it occurs in the central areas with smalls zones in the southern and northern parts of the study area. The presence of this area could be attributed to the low gradient slopes to a high density of fracking. These two criteria may be associated to the thicknesses of alterite or saprolites whose importance could justify the existence of a good level aquifer. The quality of these results could be justified by the fact that 


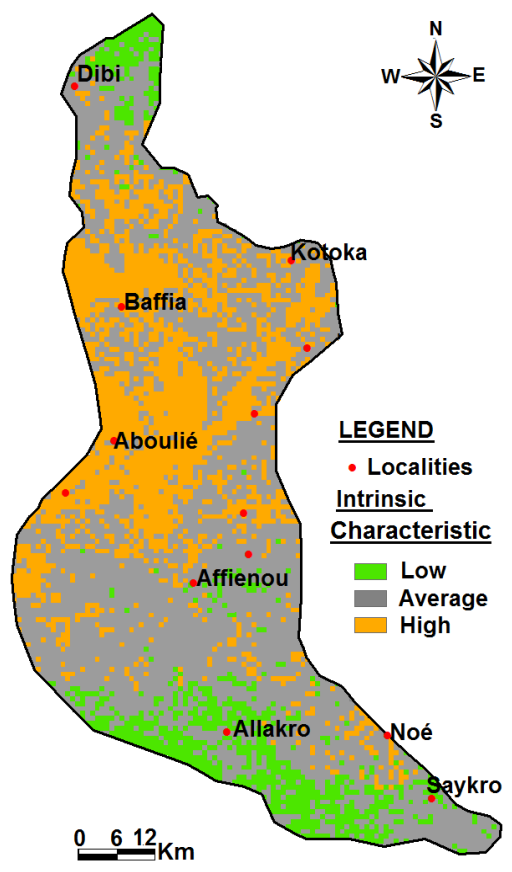

Figure 2. Map of intrinsic characteristics.

more than $60 \%$ of the drilling whose yield are greater than $5 \mathrm{~m}^{3} / \mathrm{h}$ are met in these zones of high availability. The $40 \%$ existing found in the areas of existence average condition.

\section{1) Factor of waters resources}

The factor water resource highlights the presence of water in the aquifer. Its importance is a reflection of the richness of these sub-soils in groundwater. The results analysis achieved (Figure 3 ) shows that it remains dominated by the class known as average which cover almost $60 \%$ of the study area with a presence much more strengthened in the southern part. This presence decreases more and more toward the north high and low classes cover practically the same areas (16\% and $24 \%)$, they are met respectively in the center and north parts with a pocket for the high class in the North and reduced coverage in the center for the low class. The class known as good is typically observed in the sectors where the refills are often strong, accompanied by shallow groundwater. The superposition of the high yield of exploitation to this map shows that only $40 \%$ overlap to the high class and low against $20 \%$ in the class known as average.

\section{2) Potentiality of groundwater}

The mapping of potentialities in groundwater developed from the GIS and the MCA (Figure 4) has allowed obtaining important results from the crossing of the intrinsic characteristics and water resource factors. The analysis of these results reveals a domination of the class average $(60 \%)$ which covers on a regular basis throughout the study area with the exception of the center where this presence is less observed. With regard to the high class or good potentiality (20\%) in groundwater that is the most sought, it is found strewn on the whole of the study area with however a more presence in the center. In these areas where 


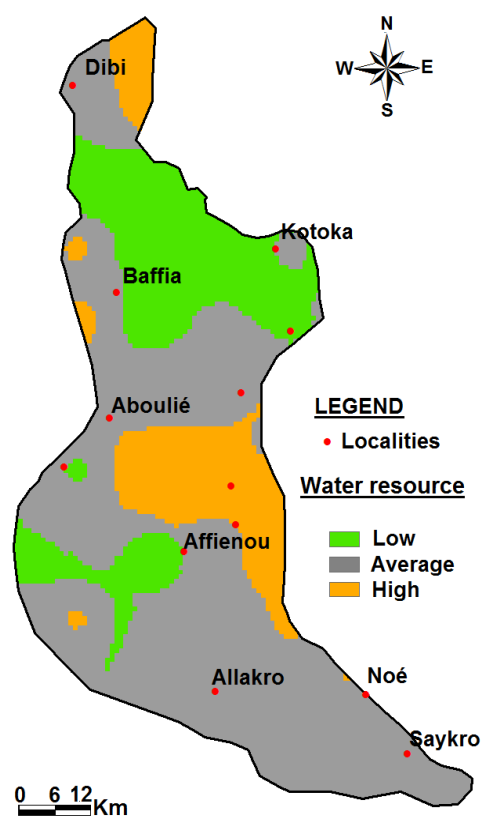

Figure 3. Map of water resources.

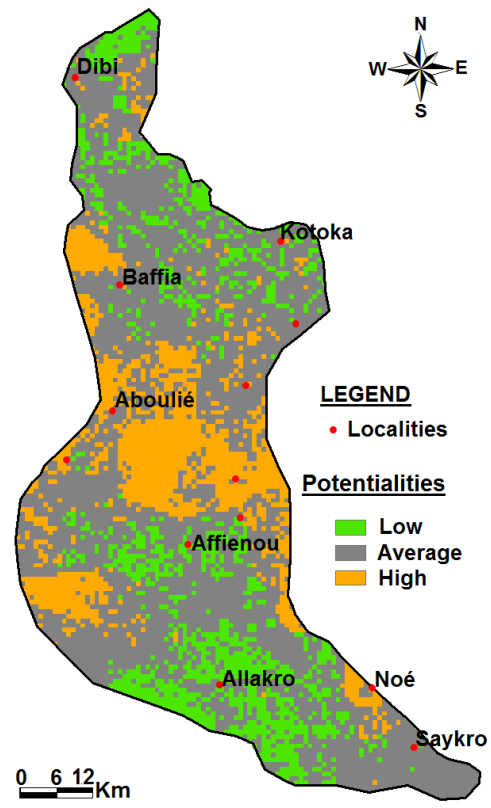

Figure 4. Map of potential in underground water.

generally the conditions of existence in water are good. In areas of good conditions for water availability, significant recharges of groundwater were observed; they are associated with weak slopes, fracturing and significant saprolite layers. These areas are the preferential areas for positioning the drilling. In these areas, even if the fractures are not captured, the important layers of alterite could give birth to aquifers of alterite often providing good flows. The superposition of the high flows reveals that $40 \%$ of these large flow rates are located in the areas of good potential. 


\section{Discussion}

The mapping of potential sites in underground water is a better approach to reduce the many observed rates of failure during the drilling of boreholes. It allows targeting specific areas of investigation, and minimizing failures, and improvement of productivity on future tasks. The analysis of the results showed that the study area is still dominated by areas of medium potential that could be justified by an alternation of low to medium livelihood zones associated with areas of good water resources. Regards to the areas of good potential in groundwater that are the most sought after, their presence is noticed in the areas where usually the conditions of existence in water are good. In these areas, we note the presence of a strong reloads associated with slopes generally weak, to a significant fracturing and layers of saprolites. The importance of these criteria in the availability of water resources has already been reported through several works especially with regards to the slope [13]. For saprolites, studies of [9] have shown that they could reach a good level aquifer with porosity relatively high, up to $5 \%$ to $30 \%$, particularly within the coarse granites. The importance of saprolite in groundwater availability has been also shown by [7] in Benin. Thus, where they are saturated with water, the saprolites ensure the capacitive function of the aquifer composite. The water potential of these layers falls significantly for formations at low quartz content as the shale. This horizon is mostly clay and very low permeability [20]. The importance of the nature of the geological formation in the existence of classes of good potential was also shown by the works [21]. The combined use of these three criteria for the modeling of groundwater availability has already been successfully adopted by [22] in the high valley of the Ouémé watershed in Benin. The role of the recharge in the power supply of the water is no longer demonstrated because it is the more important source of Groundwater supply especially in semi-arid regions [8]. Concerning the contribution of this recharge in the variation in water levels in the aquifer, the work of [17] has stressed the relationship that exists between these two criteria. This relationship could however strongly vary the saprolites nature according to their clay content it would contribute to delay the journey of seepage water toward the water. The link between the recharge and these levels of water was also demonstrated by the work of [23] which has further fallen the importance of these static levels in the aquifer. In effect, according to their results, water levels in an aquifer represent an important parameter in the hydrology of groundwater because they allow a careful analysis and detailed of its spatio-temporal variation and reveal useful information about the system aquifer. These studies have indicated that the recharge was still one of the parameters which influence this parameter in addition to the evapotranspiration, surface waters and oceans. Concerning the coincidence between the strong flows and areas of good potential, it could be explained by the strong variation of geological formations in the area. Indeed, in the area of geological mapping performed the shown the existence of an alternation of granitoids of different sizes and schistose formations [24]. 


\section{Conclusion}

At the end of this study on the modeling of groundwater potential from GIS and CMA several important results have been obtained. These results show that both of these methods make an important contribution to groundwater prospecting by the quality of the parameters or criteria that have been used. They made it possible to map on the Ehania watershed the various potential classes that remain dominated by the middle classes that are found throughout most of this area. In terms of the good potential class that is the most sought after area for groundwater prospecting, they cover only $25 \%$ of the study area. These zones are generally located in the central part, mainly in areas where the low slopes are associated with a large recharge with a thick layer of saprolite. This study has finally highlighted the parameters that play an important role in the availability of groundwater resources. This is the slope, the fracturing and the drainage network. To these intrinsic characteristics, it is necessary to associate the criteria which inform on the water resources which are the recharge and the static levels.

\section{Conflicts of Interest}

The authors declare no conflicts of interest regarding the publication of this paper.

\section{References}

[1] Assaf, H. and Saadeh, M. (2008) Geostatistical Assessment of Groundwater Nitrate Contamination with Reflection on DRASTIC Vulnerability Assessment: The Case of the Upper Litani Basin Lebanon. Water Resource Management, 23, 775-796. https://doi.org/10.1007/s11269-008-9299-8

[2] Dewandel, B., Lachassagne, P., Zaidi, F.K. and Chandra, S. (2011) A Conceptual Hydrodynamic Model of a Geological Discontinuity in Hard Rock Aquifers: Example of a Quartz Reef in Granitic Terrain in South India. Journal of Hydrology, 405, 474-487. https://doi.org/10.1016/j.jhydrol.2011.05.050

[3] Koudou, A., Adiaffi, B., Assoma, T.V., Sombo, A.P., Amani, E.M.E. and Biemi, J. (2013) Conception d'un outil d'aide à la décision pour la prospection des eaux souterraines en zone de socle du sud-est de la Côte D'Ivoire. Geo-Eco-Trop, 37, 211-226.

[4] Soro, D. (2017) Caractérisation et modélisation hydrogéologique d'un aquifère en milieu de socle fracturé: Cas du site expérimental de Sanon (région du plateau central au Burkina Faso). Thèse en Cotutelle, Université Pierre et Marie Curie-Paris, Institut International d'Ingénierie de l'Eau et de l'Environnement, Paris, 236 p.

[5] Maréchal, J.C., Dewandel, B., Ahmed, S., Galeazzi, L. and Zaidi, F.K. (2006) Combined Estimation of Specific Yield and Natural Recharge in a Semi-Arid Groundwater Basin with Irrigated Agriculture. Journal of Hydrology, 329, 281-293. https://doi.org/10.1016/j.jhydrol.2006.02.022

[6] Wyns, R., Dewande, L.B. and Lachassagne, P. (2015) Origine de la fracturation des aquifères de socle: Quels sont les facteurs qui contrôlent les propriétés de l'horizon fissuré? Actes de la Conférences, 20èmes Journées techniques du Comité Français d Hydrogéologie, La Roche-sur-Yon, 11-13 Juin 2015, 8 p.

[7] Vouillamoz, J.M., Tossa, A.Y.A., Chatenoux, B. and Kpegli, K.A.R. (2015) Propriétés 
des aquifères de socle du Bénin: Analyse multi-variables et multi-échelles des paramètres de contrôle. Actes de la Conférences, 20èmes Journées techniques du Comité Français d Hydrogéologie, La Roche-sur-Yon, 11-13 Juin 2015, 8 p.

[8] Perrin, J., Ferrant, S., Massuel, S., Dewandel, B., Maréchal, J.C., Aulong, S. and Ahmed, S. (2012) Assessing Water Availability in a Semi-Arid Watershed of Southern India Using a Semi-Distributed Model. Journal of Hydrology, 460-461, 143-155. https://doi.org/10.1016/j.jhydrol.2012.07.002

[9] Doumouya, I., Dibi, B., Kouame, K.I., Saley, B., Jourda, J.P., Savane, I. and Biemi, J. (2012) Modelling of Favourable Zones for the Establishment of Water Points by Geographical Information System (GIS) and Multicriteria Analysis (MCA) in the Aboisso Area (South-East of Côte D'Ivoire). Environmental Earth Science, 67, 1763-1780. https://doi.org/10.1007/s12665-012-1622-2

[10] Barrat, J.M. and Gutierrez, A. (2015) Cartographie \& Validation des Potentialités en Eaux Souterraines en Domaine de Socle sous Climat Tropical: Exemple du Burundi. Actes de la Conférences 20èmes Journées techniques du Comité Français d Hydrogéologie, La Roche-sur-Yon, 11-13 Juin 2015, 6 p.

[11] Dibi, B. (2008) Cartographie des sites potentiels d'implantation des points d'eau dans le département d'aboisso (sud-est de la côte D'Ivoire): Apport du sig et de l'analyse multicritère. Thèse de doctorat d'Université de Cocody, 156 p.

[12] Ettazarini, S. and El Mahmouhi, N. (2004) Vulnerability Mapping of the Turonian Limestone Aquifer in the Phosphates Plateau (Morocco). Environmental Earth Science, 46, 113-117. https://doi.org/10.1007/s00254-004-1022-3

[13] Prasad, R.K., Mondal, N.C., Pallavi, B., Nandakumar, M.V. and Singh, V.S. (2008) Deciphering Potential Groundwater Zone in Hard Rock through the Application of GIS. Environmental Geology, 55, 467-475. https://doi.org/10.1007/s00254-007-0992-3

[14] Baïsset, M., Gutierrez, A., Gandolfi, J.M., Mathieu, F., Dewandel, B., Boisson, A. and Bechelen, L. (2015) Prospection hydrogéologique de l'aquifère migmatitique de Grand Santi-Guyane Française-Retour d'expérience. Actes de la Conférences, 20èmes Journées techniques du Comité Français d Hydrogéologie, La Roche-sur-Yon, 11-13 Juin 2015, 8 p.

[15] Maréchal, J.C., Sarma, M.P., Ahmed, S. and Lachassagne, P. (2002) Establishment of Earth Tide Effect on Water-Level Fluctuations in an Unconfined Hard Rock Aquifer Using Spectral Analysis. Current Science, 83, 10-20.

[16] Shankar, R.M.N. and Mohan, G. (2006) Assessment of the Groundwater Potential and Quality in the Bhatsa and Kalu River Basins of Thane District, Western Deccan Volcanic Province of India. Environmental Geology, 49, 990-998. https://doi.org/10.1007/s00254-005-0137-5

[17] Maréchal, J.-C., Varma, R.R.M., Riotte, J., Vouillamoz, J.-M., Mohan Kumar, M.S., Ruiz, L., Sekhar, M. and Braun, J.-J. (2009) Indirect and Direct Recharges in a Tropical Forested Watershed: Mule Hole, India. Journal of Hydrology, 364, 272-284. https://doi.org/10.1016/j.jhydrol.2008.11.006

[18] Saaty, T.L. (1977) A Scaling Method for Priorities in Hierarchical Structures. Journal of Mathematical Psychology, 15, 234-281. https://doi.org/10.1016/0022-2496(77)90033-5

[19] Dibi, B., Plagnes, V., Konan-Waidhet, A.B. and Savane, I. (2015) Définition d'une méthodologie de dimensionnement des zones de protection des ouvrages de captages d'eaux souterraines en zone de socle. Cas de la zone test du bassin versant d'Ehania (Sud-est de la Côte D’Ivoire). Actes de la Conférences, 20èmes Journées 
techniques du Comité Français d'Hydrogéologie, La Roche-sur-Yon, 11-13 Juin 2015, 8 p.

[20] Lachassagne, P., Dewandel, B. and Wyns, R. (2015) Le modèle conceptuel hydrogéologique des aquifères de socle altéré et ses applications pratiques. 20èmes Journées techniques du Comité Français d Hydrogéologie, La Roche-sur-Yon, 11-13 Juin 2015, 8 p.

[21] Kouassi, W.F., Kouassi, K.A., Mangoua, M.J., Kamenan, Y.M. and Kouadio, Z.A. (2019) Evaluation des potentialités en eau souterraine de la portion Ivoirienne du bassin versant du Niger. International Journal of Innovation and Applied Studies, 25, 774-784.

[22] Dickson, N., Comte, J.-C., Vouillamoz, J.-M., Koussoube, Y. and Ofterdinger, U. (2015) Contrôles structuraux à grande échelle des propriétés hydrogéologiques et modélisation des eaux souterraines du bassin de socle de la haute vallée de l'Ouémé (Bénin, Afrique de l'Ouest). Actes de la Conférences 20èmes Journées techniques du Comité Français d Hydrogéologie, La Roche-sur-Yon, 11-13 Juin 2015, 8 p.

[23] Wyns, R., Baltassat, J.-M., Lachassagne, P., Legchenko, A., Vairon, J. and Mathieu, F. (2004) Application of Proton Magnetic Resonance Soundings to Groundwater Reserve Mapping in Weathered Basement Rocks (Brittany, France). Bulletin de la Société Géologique de France, 175, 21-34. https://doi.org/10.2113/175.1.21

[24] Hirdes, W., Konan, K.G., N'da, D., Okou, A., Sea, P. and Zamble, Z.B. (2004) Carte géologique de la Côte D’Ivoire au 1/100 000. Partie Nord de la zone d'Aboisso. Feuille Grand Bassam, Coupures 4a, b, b bis. 